\title{
Music and Domestic Devotion in the Age of Reform
}

\author{
Iain Fenlon
}

In the second book of his De cardinalatu, Paolo Cortesi presents the image of the ideal cardinal not only as a powerful papal bureaucrat with influence in the curia, but also as the master of a large household. ${ }^{1}$ Designed as a guide to virtuous behaviour, De cardinalatu addresses many practical aspects of the cardinal's life, including the construction, decoration, and functional operations of palaces. Heavily indebted to both Vitruvius and Alberti, Cortesi's discussion of palace-building also reflects his knowledge of real Roman examples including the imposing residence of Cardinal Raffaele Riario (now the Palazzo della Cancelleria). Cortesi's ideal palace includes not only a chapel, as might be expected, but also a music room, which should have a round and vaulted ceiling to improve the acoustic, and bronze or earthenware vases sunk into the wall cavities to amplify the sound. ${ }^{2}$ These two spaces would have functioned as the principal sites of musical activity within the palace, the former for devotional music sometimes performed in a liturgical context, the latter largely (though not exclusively) for the enjoyment of secular songs and instrumental music. Surviving domestic collections of printed and manuscript music from a number of palaces with private chapels, such as the Palazzo Massimo alle Colonne and the Palazzo Altemps, bring substance to Cortesi's words. ${ }^{3}$ In

1 Cortesi P., De cardinalatu (Castro Cortesio [i.e. San Geminiano], Nardi:1510), Lib. II, cap. II; for an English translation with introduction and commentary see: Weill-Garris K. - D'Amico J., “The Renaissance Cardinal's Ideal Palace: A Chapter from Cortesi's 'De Cardinalatu”, Memoirs of the American Academy in Rome 35 (1980) 45-123.

2 Pirrotta N., "Musical and Cultural Tendencies in Fifteenth-Century Italy", Journal of the American Musicological Society 19 (1966) 127-161, 152-153, reprinted in Music and Culture in Italy from the Middle Ages to the Baroque (Cambridge, MA.: 1984) 80-112. For the evolution of the music-room as a type see: Howard D. - Moretti L. (eds.), The Music Room in Early Modern France and Italy: Sound, Space and Object (Oxford: 2012).

3 Lippmann F., "Musikhandschriften und-Drucke in der Bibliothek Massimo", Analecta musicologica 17 (1976) 254-295; for further discussion of the Massimo partbooks copied ca. 1530 see: Fenlon I. - Haar J., The Italian Madrigal on the Early Sixteenth Century: Sources and Interpretation (Cambridge: 1988) 117-118. For the Altemps partbook copied for the family chapel during the period of Duke Giovanni Angelo Altemps see Couchman J.P., "Musica nella

(C) IAIN FENLON, 2019 | DOI:10.1163/9789004375871_006

This is an open access chapter distributed under the terms of the prevailing CC-BY-NC-ND License at the time of publication. 
Rome, with its high density of clerical households at all levels of society, the incorporation into the daily routine of various forms of devotional music was a feature of domestic life.

Venice presents a different impression. While it is musicians (among others) that populate the Arcadian expanses of Veronese's frescoes at the Villa Maser, it seems unlikely that we shall ever know precisely what kind of music graced these interiors, and it is hard to progress beyond generalisation to a more detailed understanding of the place of music in the private lives of the citizens of the Republic. ${ }^{4}$ Occasional clues are all the more tantalizing on account of their scarcity. In Giorgio Vasari's account of Jacopo Tintoretto's life, it is remarked that the artist took particular pleasure in playing music on a number of instruments, and even if Tintoretto's paintings contain comparatively few references to music-making, there is no doubt that the family house was one in which music was cultivated. ${ }^{5}$ Ridolfi later claimed that as a young man Jacopo played the lute 'et altri bizzari stromenti da lui inventati'. ${ }^{6}$ Giulio Zacchino, a minor composer who was employed as organist at San Giorgio Maggiore in the early 1570s, was charged with teaching Jacopo's daughter Marietta how to sing and play the harpsichord; according to Raffaello Borghini's description of her, she could also play the lute. ${ }^{7}$ It is suggestive of the importance that music held for her that Marietta's well-known self-portrait shows her standing in front of a harpsichord while holding an open part book [Fig. 4.1]. As is sometimes the case in paintings of this type, the music itself is legible and forms part of our reading of the picture. Here the pages fall open to reveal the upper part, presumably Marietta's own voice type, of Philippe Verdelot's celebrated madrigal 'Madonna per voi ardo', a choice that presumably relates to some important and now lost event in her personal life. Musical inscriptions, including the opening of Andrea Gabrieli's 'Quanto lieta ver noi sorge l'Aurora' evidently copied from printed books also occur in Jacopo's allegorical painting of music,

cappella di Palazzo Altemps a Roma", in Lefevre R. - Morelli A. (eds.), Lunario romano 15 (1986): Musica e musicisti nel Lazio 167-183.

4 Murano M., "Musica nelle ville venete", in Della Seta F. - Piperno F. (eds.), In cantu et sermone. For Nino Pirrotta on his 8oth Birthday (Rome: 1989) 175-183.

5 Giorgio Vasari, Le vite de più eccellenti pittori (Florence, Torrentino: 1568), R. Bettarini P. Barocchi (eds.), 6 vols. (Turin: 1963-1989) V, 468. For an overview of Tintoretto's use of musical subject-matter see: Weddigen E., "Jacopo Tintoretto und die Musik", Artibus et historiae $10(1984) 67-119$.

6 'And other bizarre instruments he invented', Carlo Ridolfi, Vita di Giacopo Robusti detto il Tintoretto (Venice, Guglielmo Oddoni: 1642) 88.

7 Raffaello Borghini, Il riposo (Florence, Giorgio Marescotti: 1584) $55^{8}$. 


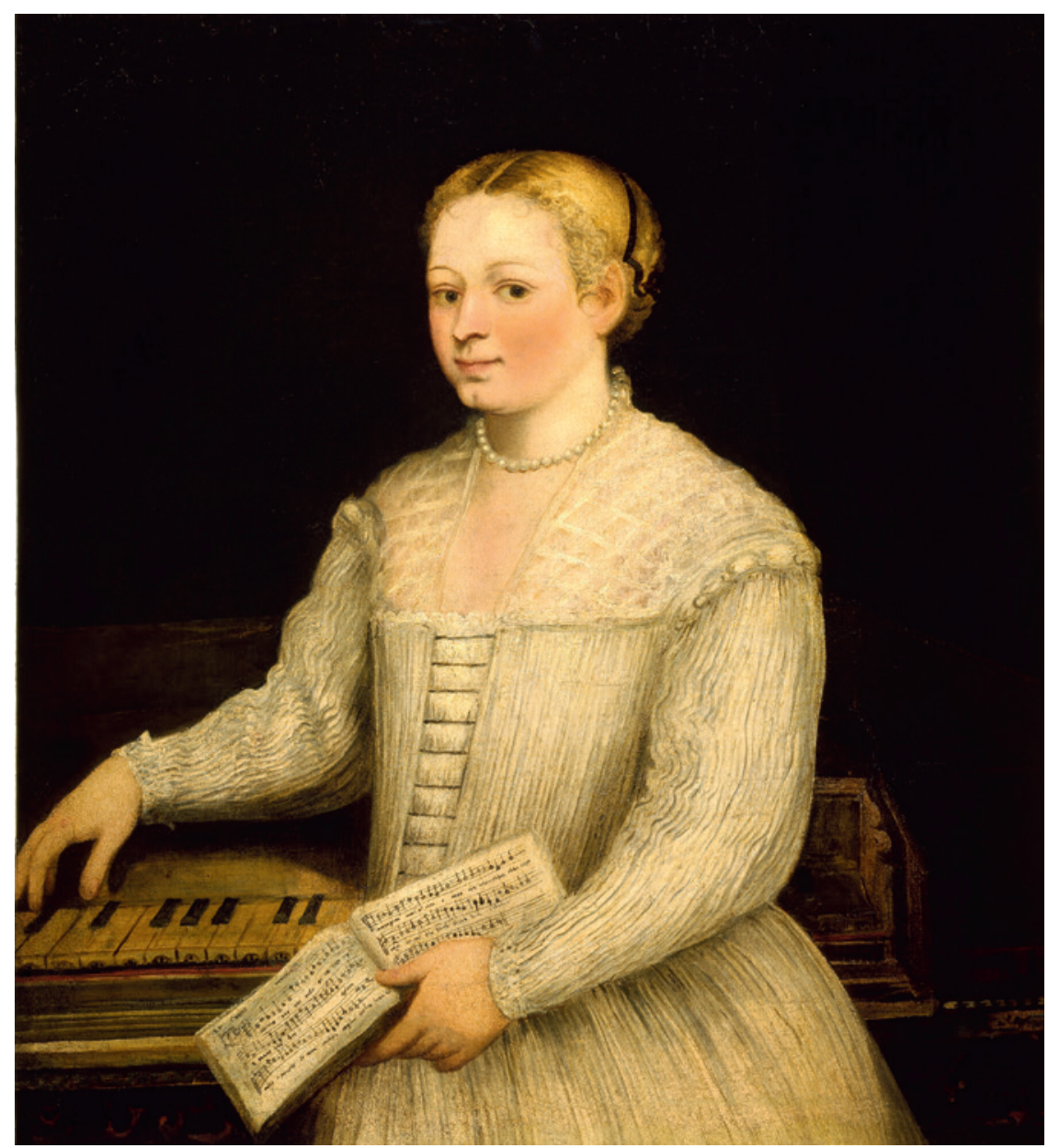

FIGURE 4.1 Marietta Robusti, "Self Portrait", ca. 1580 . Oil on canvas, $93.5 \times 91.5 \mathrm{~cm}$. Florence, Galleria degli Uffizi

(C) SCALA PICTURE LIBRARY, FLORENCE

one of a number that he painted, now in Dresden, confirming perhaps his musical literacy and knowledge of the madrigal repertory [Fig. 4.2]. ${ }^{8}$

8 Slim H.C., "A Painting about Music at Dresden by Jacopo Tintoretto", Exploration in Renaissance Culture 13 (1987) 1-18; id., "Tintoretto's Music-Making Women at Dresden", Imago musicae 4 (1987) 45-76; Rosand D., Painting in Cinquecento Venice (New Haven and London: 1986) 159-164; De Girlami Cheney L., “Jacopo Tintoretto's Female Concert: The Realm of Venus", Journal of Literature and Art Studies 6 (2016) 478-499. 


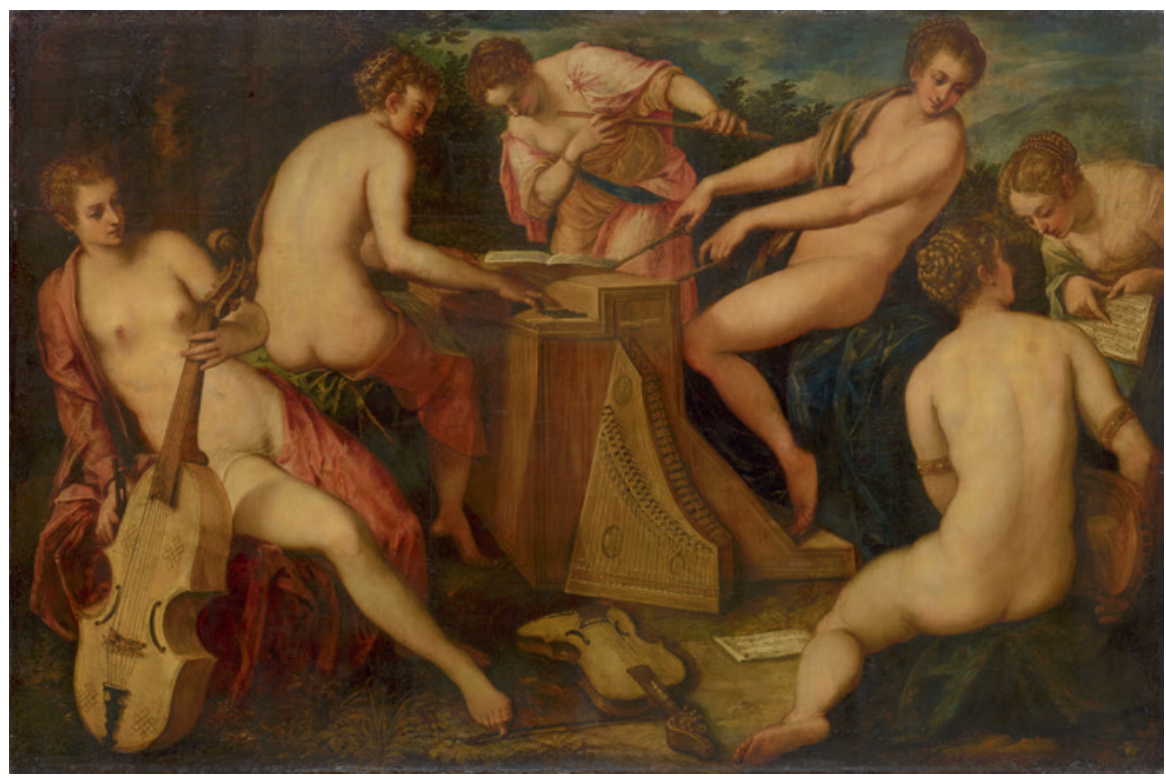

FIGURE 4.2 Jacopo Tintoretto, "Women making music", after 1566 . Oil on canvas, $142 \times 214 \mathrm{~cm}$. Dresden, Gemäldegalerie Alte Meister, Staatliche Kunstsammlungen.

(C) ELKE ESTEL/HANS-PETER KLUT

Such rare insights into the musical life of an admittedly rather untypical household are all the more precious because of the general lack of information about the place of music in the domestic world of sixteenth-century Venetians. The richly-textured image of Venetian musical activity in the period is largely based on what is known about music in public contexts; by contrast, our knowledge of musical activities a casa, even in the palaces that line the Grand Canal let alone in the houses of the affluent merchant class, is scant, occasional, and random. Venetians (unlike Florentines) did not routinely write ricordanze or family memoirs that might help..$^{9}$ In order to penetrate the walls of the Venetian house and hear its domestic sounds requires attention to other kinds of information. ${ }^{10}$

Among these is the post-mortem inventory, a group of almost eight hundred of which, deposited in the Cancelleria inferiore in the Archivio

$9 \quad$ Grubb J., "Memory and Identity: Why Venetians didn't keep ricordanze", Renaissance Studies 8 (1994) $375^{-3} 87$.

$10 \quad$ For some of the difficulties see Dennis F., "Sound and Domestic Space on Fifteenth- and Sixteenth-Century Italy", Studies in the Domestic Arts 16 (2008-9) 7-19. 
di Stato, have been used extensively by historians of material culture. ${ }^{11}$ Chronologically they stretch from 1497 to 1630 , and are somewhat unevenly distributed over the decades; the traditional three estates of Venetian society are represented, though not equally. ${ }^{12}$ One collection of books to emerge from these inventories belonged to Girolamo Ferro, a patrician whose library of almost 300 volumes included classics, law, history, and 'libri otto de musica, coperti de cuoio', probably a reference to two sets of partbooks containing vocal music for four voices. ${ }^{13}$ The presence of music serves as a useful reminder that at the higher end of the social scale, music in the Italian home was sung from notation by the musically literate. Girolamo da Modena Solimatis, a wealthy dealer in spices, owned a shop at San Bartolomeo, a villa near Padua, and a main residence in Venice. There the salone contained an organ in a gilded case, a clavicembalo in an ebony one, five lutes, and a collection of flutes. Forty-three 'libri a stampa di diverse sorte' were kept in a trunk, and fifty 'libri da canto' in another. ${ }^{14}$ Somewhat similar in character are a number of inventories of the possessions of members of the Flemish merchant community. ${ }^{15}$

For the wealthier members of society, musical skills were acquired by private tuition at the hands of music masters. A glimpse into this world is provided by the records of the Inquisition, whose investigations had led them to enquire into the activities of a schoolmaster from Cremona, Francesco Scudieri, described as a 'man of letters who teaches music and the Italian language to Germans and other northerners' in Venice. ${ }^{16}$ It was these social contacts that had aroused suspicion, and as part of its inquiries the Holy Office made a list

11 ASVe, Cancelleria inferiore (from hence forward $C I$ ), Miscellanea bb. 34-45. See, inter alia: Fortini Brown P., "Behind the Walls: The Material Culture of Venetian Elites", in Martin J. - Romano D. (eds.), Venice Reconsidered: The History and Civilization of an Italian City-State, 1297-1797 (Baltimore: 2000) 295-338; id., Private Lives in Renaissance Venice: Art, Architecture and the Family (New Haven and London: 2004); Morse M.A., "Creating Sacred Space: The Religious Visual Culture of the Renaissance Venetian casa", Renaissance Studies 21 (2007) 151-184; Palumbo Fossati I., Dentro le case. Abitare a Venezia nel Cinquecento (Venice: 2013).

12 On the limitations of inventories as historical evidence see Thornton D., The Scholar in his Study: Ownership and Experience in Renaissance Italy (New Haven and London: 1997) 15-20.

13 ASVe, $C I$ b. 40/43 (29 December, 1562).

14 'Printed books of different topics', and 'singing books', Ibid. ASVe, CI b. 40/73 (14 April-17 May, 156o); separate inventory for the contents of his shop in b. 40/44 (12-25 August, 156o).

15 Brulez W., Marchands flamands à Venise, I: 1568-1605 (Brussels-Rome: 1965) 630-643. (Francesco Vrins); Devos G. - Brulez W., Marchands flamands a Venise II: 1606-1621 (Brussels - Rome: 1986) 799-811 (Carlo Helman).

16 ASVe, Sant'Uffizio (from hence forward $S U$ ) b. 15, processo 15: 'Io facio profession de Lettere et insegnar musica et lengua taliana a todeschi et altri oltramontani'. 
of Scudieri's library. Apart from a good deal of music as might be expected, much of it rather old-fashioned, it also included medical treatises, Bembo's Prose della volgar lingua, a number of works by Erasmus, Demosthenes in Greek, and Cicero, Hesiod, Homer, Quintilian, Terence, and Virgil in Latin. ${ }^{17}$ Another professional musician, Pietro Palombino, a singing-man at St. Mark's Basilica in Venice, owned two breviaries, two manuscripts containing music, and a couple of major works of fifteenth-century music theory: a manuscript of the De musica by Johannes Tinctoris, and one of Franchino Gaffurius's published theoretical treatises. ${ }^{18}$ One of the most impressive collections of music books and books about music in the city was that of the composer and theorist Gioseffo Zarlino, but sadly the notary who made the post-mortem inventory only counted his books according to format rather than listing titles; except for the Inquisitors, who had different objectives, this was the most efficient way of working. ${ }^{19}$

As well as being at the heart of the music printing and publishing trade, Venice was also one of the most important Italian centres for the manufacture of musical instruments. Two separate inventories of the goods of the lutemaker Moisé Tieffenbrucker list hundreds of finished and unfinished pieces kept on his premises; he was a distinguished maker, and a number of his instruments have survived [Fig. 4.3] ${ }^{20}$ Another craftsman, Andrea Bassi, was storing more than two hundred lutes, more than half of which were unfinished, when the contents of his house and workshop were listed on his death; he also repaired instruments and dealt in second-hand ones. ${ }^{21}$ Although musical instruments, and above all lutes, occur in some quantity in these lists, the operations of Bassi and the Tieffenbruckers were aimed not only at a local clientele, but also at wealthy visitors such as Raimund Fugger; an inventory of his instrument collection, made in 1566, shows that he bought lutes made from exotic materials such as ivory and sandalwood rather than the more common

17 ASVe, $S U$, b. 15, Scudieri. See: Mackenney R., Tradesmen and Traders: The World of the Guilds in Venice and Europe, c.1250-c.1650 (London and Sydney: 1987) 183; Ongaro G.M., "The Library of a Sixteenth-Century Music Teacher", The Journal of Musicology 12 (1994) 357-375.

18 ASVe, $C I$, b. 36/16 (Palombino, 1 May 1535).

19 Palumbo Fossati I., "La casa veneziana di Gioseffo Zarlino nel testamento e nell'inventario dei beni del grande teorico musicale", Nuova rivista musicale italiana (1986) 633-649; and Palumbo Fossati, Dentro le case 274-277.

20 Ongaro G., "The Tieffenbruckers and the Business of Lute-Making in Sixteenth-Century Venice", The Galpin Society Journal 4 (1991) 46-54.

21 ASVe, CI b. $36 / 35$ (Bassi, 27 January 1536). See: Toffolo S., Antichi strumenti veneziani, 15001800 (Venice: 1987) 195-196. 


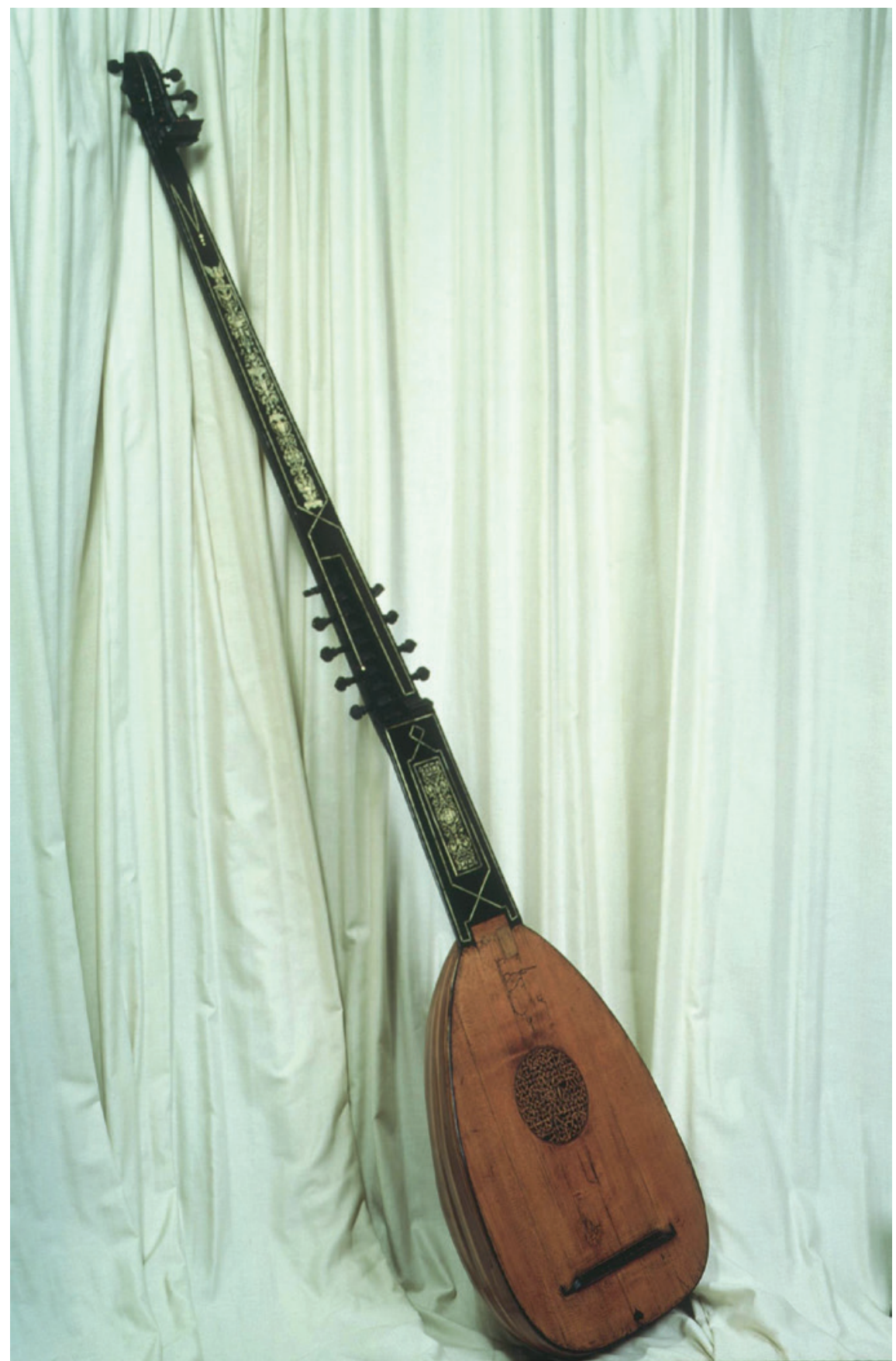

FIGURE 4.3 Wendelin Tieffenbrucker, Chitarrone (probably originally a lute but later converted), made in Padua, 1592. Pinewood with ebony and ivory, $170 \times 34 \mathrm{~cm}$. London, Victoria and Albert Museum

(C) VICTORIA AND ALBERT MUSEUM, LONDON 
European hardwoods. ${ }^{22}$ At the higher end of manufacture, instruments were often prized for their decorative qualities. Vincenzo Pasqualigo, a man of considerable means, owned lutes, a violin, a couple of monochords, and a dulcimello, the later described as 'intagliado' and 'soazado' (carved). ${ }^{23}$ Possession of such objects, perhaps acquired for the beauty of their craftsmanship, does not imply that they were used. ${ }^{24}$

That some well-to-do members of the merchant class should have musical interests, and that they acquired printed music and instruments, is to be expected. More surprising perhaps is that the ownership of musical instruments was so widespread throughout Venetian society. Notaries record them frequently in modest houses, and most patrician and merchant households owned at least one instrument and often more. Marco di Giacomo was a cloth dyer, and Giacomo Manolesso a member of the minor nobility. One thing that these two men from different social classes shared was that they owned no books of any kind but did have musical instruments: Manolesso two harpsichords, 'one large the other small', Marco di Giacomo a single 'arpicordo'. ${ }^{25}$ The frequency with which lutes are recorded in inventories is a reminder that not all sixteenth-century luteplayers needed printed tablatures in order to make music, any more than do twenty-first century guitar players. In an age when the art of memory was developed to an extent that we can only dimly imagine, much was hummed and strummed, improvised, and memorised. It is in thinking about these musical practices, rather than merchant class performances from printed books and manuscripts, that some sort of notion of more typical experiences of devotional music emerges.

\section{2 \\ Domestic Devotions and Music}

The increasing availability of music of all kinds in the course of the century encouraged forms of domestic music making in which distinctions between sacred and secular genres became blurred. ${ }^{26}$ Pieces which began life as madrigals were often published as contrafacta with sacred texts, and instrumental duos

\footnotetext{
22 Alton Smith D., "The Musical Instrument Inventory of Raymund Fugger", Galpin Society Journal 33 (1980) 36-44.

23 ASVe, $C I$ b. 38/74 (Pasqualigo, 7 June 1553).

24 Thornton P., The Italian Renaissance Interior, 1400-160o (London: 1991) 272.

25 ASVe, $C I$ b. 37/6 (Manolesso, 29 June, 1543).

26 For the impact of print see: Fenlon I., Music, Print and Culture in Early Sixteenth-Century Italy (London: 1995); Bernstein J.A., Print Culture and Music in Sixteenth-Century Venice (Oxford: 2001).
} 
could be easily fitted out with words. Partbooks devoted to music for a single voice-type were often bound together so as to make larger anthologies containing madrigals, motets, and instrumental music sewn into one set of covers; the result was a personal collection of pieces suitable for a variety of functions within the home. One characteristic example among many includes not only books of motets by Willaert, Gombert, and Jacquet of Mantua, but also three early editions of Jan Gero's Il primo libro de madrigali italiani et canzonifrancesi a due voci, one of the most frequently reprinted editions (more than twenty are known) of the sixteenth and seventeenth centuries. ${ }^{27}$ Similarly, the small collection of music assembled around the middle of the sixteenth century by Count Giovanni Severini, a member of the Accademia Filarmonica of Verona, contains editions of both secular and sacred music. ${ }^{28}$

The market for sacred music for performance in the home was also partly satisfied by madrigali spirituali, settings of devotional texts in the vernacular. Together with their near-relative the lauda spirituale, which was often different only to the extent of being a setting of a strophic text, these were the main components of the repertory of printed polyphonic settings of Italian devotional verse. To these should be added falsobordoni, pieces cast in a more 'popular' manner than the more socially restricted 'high art' of the spiritual madrigal. Since their stylistic simplicity, transparent textures, and syllabic declamation made falsobordoni (a type of chordal recitation based on the melody of a Gregorian psalm tone) both easier to sing and to listen to, they came closer than any other form of composed polyphony to the ideals of the reformers, for whom accessibility was the key concept. From here it is but a short step to the practice of improvised polyphony, which were related to oral traditions of improvised singing rather than written composition. These different genres span a wide range of devotional music that was available throughout the peninsula for use not only in confraternities and churches, but also in the home.

A good place to start is with the domestic shrine. Images of the Virgin, and small Byzantine icons played a distinctive role in the devotional life of early modern Venice. They were to be found everywhere, from the precious icon of the Madonna Nicopeia kept in St. Mark's Basilica, to the small madonniere often worshipped in Venetian houses. Their presence, often in a number of rooms in the house, remind us that the musical life of the Renaissance home

27 Palermo, Biblioteca Nazionale, Rari 1.a.29.32; see Lewis M.S., Antonio Gardano, Venetian Music Printer 1538-1569: A Descriptive Bibliography and Historical Study, I (New York and London: 1988) 146-147.

28 Bernstein J.A., Music Printing in Renaissance Venice: The Scotto Press (1539-1572) (New York and Oxford: 1998) 948. 
was not merely secular, but was thoroughly permeated by devotional activity. ${ }^{29}$ In front of these shrines prayers were said and devotional songs sung. ${ }^{30}$

Through her long-standing association with the foundation of the city itself, which according to legend had been founded on the Feast of the Annunciation, the Virgin had always played a significant role in the Venetian consciousness. Throughout Italy, but particularly in Venice, her image was to be found everywhere, from the home to the street and the church. ${ }^{31}$ Combined with the historical reality that, unlike most other Italian states, Venice had never been invaded, the association of the Virgin with the foundation myth of the city produced a visualisation of the Pax Venetiana that crucially relied upon the resonances of Marian iconography. ${ }^{32}$ Both the Annunciation and the Assumption were marked as great civic celebrations, and by the end of the sixteenth century about one third of the major Marian feasts in the Venetian calendar had acquired state connotations, usually through association with important military or naval victories. These developments served to intensify the role of the Virgin in the inextricably linked rituals of civic and devotional practice both in public and in private. So too did the annual blessing of the Adriatic on the feast of the Ascension, which had grown into a complex ceremony in which Venice was symbolically re-married to the sea. ${ }^{33}$

In the private sphere, songs and prayers addressed to the Virgin - litanies, laude, and hymns such as the 'Salve Regina', were commonly to be heard, in part due to the association of the Virgin with the victory of the Holy League at Lepanto on 7 October 1571. This also marked an increase in the popularity of the cult of the rosary throughout Italy, promoted by Pius V who established the

29 Morse, "Creating Sacred Space”; Cooper D., "Devotion", in Ajmar-Wollheim M. - Dennis F. (eds.), At Home in Renaissance Italy, exh. cat., Victoria \& Albert Museum (London: 2006) 190-203.

30 Often flanked by candlesticks, these icons, together with painted images in the Western tradition, constituted the focal point for devotion in the home. Lower down the social scale cheap woodcuts of the Virgin and Child, nailed to the wall or glued to doors served a similar purpose. See Kasl R., "Holy Households: Art and Devotion in Renaissance Venice", in Karl R. - Christiansen K. (eds.), Giovanni Bellini and the Art of Devotion (Indianapolis: 2004) 59-89; Morse, "Creating Sacred Space" 159-63, 165-70; Pon L., A Painted Icon in Early Modern Italy: Forli's Madonna of the Fire (Cambridge: 2015) 46-50.

31 Muir E., "The Virgin on the Street Corner: The Place of the Sacred in Italian Cities", in Ozment S. (ed.), Religion and Culture in the Renaissance and Reformation (Kirksville, MO: 1989) 7-41.

Rosand M., Myths of Venice: The Figuration of a State (Chapel Hill: 2005) 44-46; Fenlon I., The Ceremonial City: History, Memory and Myth in Renaissance Venice (New Haven and London: 2007) 38-45.

33 Muir E., Civic Ritual in Renaissance Venice (Princeton:1981) 119-134; Fenlon, The Ceremonial City $43^{-44 .}$ 
first Sunday of the month as the feast of Our Lady of Victory. ${ }^{34}$ Although recitation of the fifteen decades and meditation upon its mysteries once a week was the only firm obligation, public devotion played an important role; attendance at mass on the major Marian feasts of the year and to commemorate the departed was encouraged, as was participation in processions. On the first Sunday of the month, the bell of the parish church to which the confraternity was attached would be rung, and the members would process while litanies, laude, and hymns were sung. Participation in processional life was just one way in which simple devotional music could be learnt and sung; here, too, continuity of practice joined the music of the street to the domestic sphere.

In the more private space of the home, the essential features of the cult were supported by devotional objects and books such as Benedetto Zoioso's Rosario, commissioned by the confraternity attached to the church of SS. Giovanni e Paolo in Venice, or the most frequently reprinted of such titles, Luis de Granada's Rosario. ${ }^{35}$ Rosary confraternities as well as individual buyers also formed part of the market for the small bronze plaquettes showing an image of the Madonna of the Rosary which were manufactured in quantity during the last quarter of the sixteenth century; surviving perforated examples suggest that they, like medals, could be hung on the wall as objects of devotion, as well as being worn round the neck. ${ }^{36}$ Although the fifteen decades could be recited publicly and communally in church, they could also be said domestically either silently or in groups. Books of meditations upon the mysteries, intended for private devotion and often illustrated, were produced in considerable quantities, and printed versions in ottava rima could be sung to simple melodic formulas. ${ }^{37}$ Through such elaborations the Rosary became part of an integrated cult, practiced in both parish and domestic contexts, which gained additional significance in the post-Lepanto world. Spoken and sung, on both the streets and in private spaces, devotion to the Rosary was perhaps the most prominent form of Marian worship in the years after the Council of Trent.

34 Fenlon, The Ceremonial City 282-284; Winston-Allen A., Stories of the Rose: The Making of the Rosary in the Middle Ages (University Park, PA.: 1997). See also Erminia Ardissino's essay in this volume, $342-371$.

35 Benedetto Zoioso, Rosario [...] in tre parti distinto (Venice, ad instantia della veneranda Confraternità del Santissimo Rosario: 1581); Luis de Granada, Rosario della sacratissima vergine (Venice, Valvassori: 1574).

36 Fenlon, The Ceremonial City 284-285.

37 As with the compilation by the Jesuit Luca Pinelli, Libretto d'imagini, e di brevi meditationi sopra i quindici misterii della sacratissima Vergine Maria (Naples, Carlino and Pace, ex officina Horatoj Salviani: 1594). For the practice of singing verses of all kinds in ottava rima see below. 
Another common devotion practiced both inside and outside the home was the chanted litany, in particular the Litany of Loreto whose recitation, encouraged by indulgences, was often coupled to the Rosary; by the second half of the century it had become the most dominant of the various versions then in circulation. Its text focused on the legend of the holy house, in which the Virgin had allegedly been born in Nazareth, miraculously transported to its present location in the Marche. The story transformed Loreto into an important pilgrimage site, and from the middle of the sixteenth century, when the Jesuits were placed in charge of it, the popularity of the Litany spread both North and South of the Alps. ${ }^{38}$

In the home, as in the parish church or in the street during processions, the most common method of singing the litany would have been antiphonal, with each invocation being intoned by the leader of the group gathered around the family image of the Virgin, while the response 'ora pro nobis' was then sung by the rest of those present according to an extremely short simple melodic formula. In practice, the singing of a number of textually distinct litanies would have been familiar from a number of different contexts, both domestic and public. During the plague of $1575^{-76}$, the Patriarch of Venice strongly advocated that processions be held throughout the city, these to be accompanied by prayers and sung litanies 'per impetrar più facilmente la misericordia divina' ${ }^{39}$ The texts to be used, printed in one of the most popular of contemporary manuals, Alberto da Castello's Liber sacerdotalis, include the Litany of the Saints; in order to encourage the participation of those lining the route, this would have been chanted to the same simple melodic formulas used for the Litany of Loreto..$^{40}$ Alberto, who for much of his adult life lived and worked at SS. Giovanni e Paolo, was a prominent author of devotional manuals; his Rosario, another widely distributed Rosary text, went through at least thirtyfour editions. ${ }^{41}$ On other occasions, including 'in tempore pestis', the Madonna Nicopeia was carried in procession to the sound of the Litany of the Blessed Virgin Mary; the strength of the association is made explicit through the presence of the image of the Nicopeia on the title-pages of the many seventeenthcentury Venetian reprints of the text [Fig. 4.4]. ${ }^{42}$

38 Fisher A.J., "Thesaurus litaniarum: The Symbolism and Practice of musical litanies in Counter-Reformation Germany", Early Music History, 34 (2015) 45-95. Alberto da Castello, Liber sacerdotalis (Venice, Sessa and de Ravanis: 1523).

41 Alberto da Castello, Rosario della Gloriosa Vergine Maria (Venice, Sessa and de Ravanis: 1522).

Fenlon, The Ceremonial City 226-227, 322-323. 


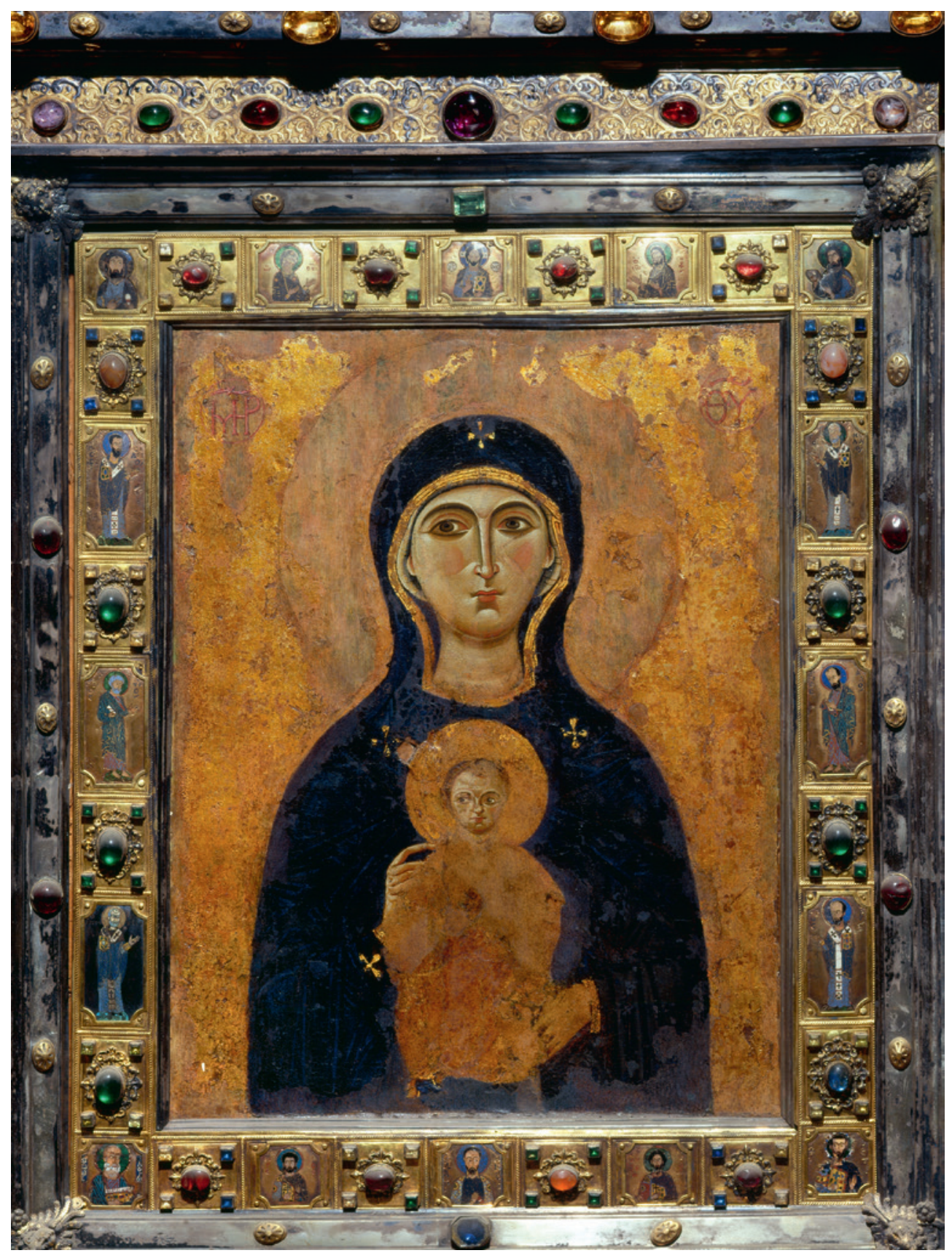

FIGURE 4.4 Madonna Nicopeia, 12th century, Byzantine. Tempera on wood, $58 \times 55 \mathrm{~cm}$. Venice, Basilica di San Marco.

(C) CAMERAPHOTO ARTE, VENICE 
While litanies were sung everywhere in Italy according to one of the standardized formulas, another popular form of devotional music, the lauda, took on different emphases according to geography. This was partly a matter of language; whereas litanies were always sung in Latin the lauda, the principal genre of non-liturgical religious song in Italy during the period, was cast in the vernacular, often using dialect forms. No particular style predominates, and polyphonic settings are found alongside simple monophony. ${ }^{43}$ As to social function, laude were sung in front of street shrines, in processions, in the home, and by confraternities. When Petrucci issued the first printed collection of laude in 1506, he devoted it entirely to works by a Venetian priest Innocentius Dammonis. ${ }^{44}$ It seems likely that this (and Petrucci's Libro secondo which soon followed), contains repertory performed by lay and clerical singers in the service of Venetian confraternities. ${ }^{45}$ Together with technically more approachable motets, simple polyphonic laude could also be sung at home by the musically more accomplished.

Savonarolan Florence

Even more widely diffused as a domestic practice was the singing of monophonic versions, which were both printed and transmitted orally. Here Florence is something of a special case. There, as elsewhere, the lauda was typically a simple setting of devotional poetry addressed to either Christ or the Virgin, but to a greater extent than any other kind of music that has come down to us, it was tightly woven into the fabric of Florentine social, religious, and civic experience. Sung in churches, monasteries, and convents as well as in the home, Florentine laude provide a detailed picture of the rich variety of interlocking musical practices, both public and private, that were heard in a quite specific urban context. At the same time, their texts illuminate some of the dominant themes of domestic devotion. In view of its long historical roots going back to the laudesi companies of the early middle ages, together with its embodiment of both lay spirituality and civic values, it is hardly surprising that the lauda was taken up so enthusiastically by the firebrand Dominican monk

43 For a comprehensive review see: Wilson B., Music and Merchants: The Laudesi Companies of Republican Florence (Oxford: 1992) 164-182.

44 Boorman S., Ottaviano Petrucci: A Catalogue Raisonée (New York: 2006), nos. 29 and 45.

45 Glixon J., "The Polyphonic Laude of Innocentius Dammonis", Journal of Musicology 8 (1990) 19-53. 
Girolamo Savonarola and his followers at the end of the fifteenth century. ${ }^{46}$ By then it had become so embedded in Florentine life that it was the obvious substitute, together with the more familiar chanted hymns of the church, for the intricate polyphony of contemporary mass and motet settings. Both possessed the virtues of broad social currency, the authority of tradition and, above all, a simplicity that made widespread participation possible. This clearly suited Savonarola's purposes as an alternative to the ornate polyphony which he took to be characteristic of the empty and cold rituals performed by a corrupt priesthood badly in need of reform. On one occasion, referring unmistakably to Medici patronage of the musical chapels at the Cathedral and Baptistery in Florence, he argued that:

God says: Take away all your beautiful polyphony. These lords have chapels of singers which seem like a rabble [...], because there stands a singer with a large voice like a calf's, and the others howl around him like dogs, and no-one understands what they are saying. Let polyphony go, and sing the plainchant ordered by the church. ${ }^{47}$

In this way, elaborate musical language was identified not only with a corrupt Church, but also with the luxurious lifestyles of princes. The fact that in its place Savonarola advocated the simplest type of lauda and chant indicates that this music was widely known. On another occasion he was even more precise in his enthusiasm for chant, saying to his congregation: 'You sing laude here every morning and that is good; but occasionally I would like to hear you sing the songs of the Church such as the 'Ave maris stella' or 'Veni creator spiritus".48 Implicit in Savonarola's remarks is that such melodies were familiar.

Perhaps rather surprisingly in the light of Savonarola's views about the destruction of genuine piety by the intrusion of secular and corrupt elements, the Florentine monophonic lauda also appropriated well-known secular melodies. Particularly close are the connections between the lauda and the specifically

46 Macey P., "The Lauda and the Cult of Savonarola", Renaissance Quarterly 45 (1992) 439-483.

47 ' [...] dice Dio: lieva via quelli tuoi belli canti figurati. Egli hanno questi signori le cappelle de' cantori che bene pare proprio uno tumulto [...], perché vi sta là un cantore con una voce grossa che pare un vitello e li altri gli cridono atorno come cani e non s'intende cosa che dichino. Lasciate andare e' canti figurati, e cantate e' canti fermi ordinati dalla Chiesa [...]', Savonarola G., Prediche sopra Amos e Zaccaria, ed. P. Ghiglieri, 3 vols. (Rome: 1971-2) II 23.

48 Savonarola, Prediche sopra Amos e Zaccaria II 80. For Medici involvement see: D’Accone F., "The Musical Chapels at the Cathedral and Baptistery during the First Half of the 16th Century", Journal of the American Musicological Society 24 (1971) 1-50. 
Florentine repertory of the canti carnascialeschi, simple songs sung during the celebration of carnival in the late fifteenth century. ${ }^{49}$ It was then that the Medicean carnival, which had been so substantially fashioned by Lorenzo de' Medici, was replaced by a Savonarolan one whose music included not only the lauda of tradition and the chants of the Church, but also sacred contrafacta of carnival songs. The explanation of this apparent paradox lies partly in musical expediency, and partly in Savonarola's general policy of adapting rather than replacing existing cultural traditions with wide appeal. ${ }^{50}$

During the sixteenth century, the entrenched practice of singing laude with Savonarolan associations, both in Tuscany in general and Florence in particular, served to commemorate the friar's life and work and acknowledge the continued vitality of his prophecies. Throughout the rest of the century, Florentine visions of religious renewal were inextricably fused with dreams of civic liberty; both were fundamental elements of the Myth of Florence - the notion of a free republic which could liberate, enrich, and ultimately redeem its citizens. ${ }^{51}$ The potency of this ideal is evident from the ferocity with which the Medici sought to suppress the remaining traces of Savonarolanism. In the face of such opposition the cult was certainly driven underground, but it was not extinguished, in part because of its preservation in a handful of Tuscan convents and monasteries. ${ }^{52}$ Prominent among them was the Dominican house of San Vincenzo in Prato, where Caterina de' Ricci, a devoted disciple, kept Savonarola's memory and ideals alive by encouraging the singing of laude with which he was particularly associated. ${ }^{53}$ Her importance for this practice is explicitly mentioned in the dedicatory letter addressed to her by the Venetian printer of Serafino Razzi's collection of laudi spirituali. ${ }^{54}$ Razzi, another Dominican, was her first biographer, and his Libro primo, clearly designed in the spirit of Savonarolan hagiography, was conceived as a monument to the Florentine

49 For a selection of the musical repertory see: Gallucci J.J. (ed.), Florentine Festival Music 1480-1520 (Madison, WI: 1981).

50 Trexler R., Public Life in Renaissance Florence (New York: 1980) 462-490.

$5^{1} \quad$ For this idea, and its use by and absorption by Savonarola, see Weinstein D., "The Myth of Florence", in Rubenstein N. (ed.), Florentine Studies: Politics and Society in Renaissance Florence (London: 1968) 15-44, and the first chapter of the same author's: Savonarola and Florence: Prophecy and Patriotism in the Renaissance (Princeton: 1970).

52 Polizzotto L., The Elect Nation: The Savonarolan Movement in Florence 1494-1545 (Oxford: 1994) 442-443. See also Stefano Dall'Aglio's essay in this volume, $375^{-3} 88$.

53 Macey P., "Infiamma il mio cor. Savonarolan Laude by and for Dominican Nuns in Tuscany", in Monson C.A. (ed.), The Crannied Wall. Women, Religion and the Arts in Early Modern Europe (Ann Arbor, MI: 1992) 161-189.

54 Serafino Razzi, Libro primo delle laudi spirituali da diversi eccell. e divoti autori (Venice, ad instantia de' Giunti di Firenze: 1563). 
tradition. As such it contains a mixture of pieces for one, two, three, and four voices, some of which clearly evoke the Savonarolan past, and many of which incorporate melodies which derive from secular songs including madrigals and carnival songs. ${ }^{55}$ Others, particularly 'Ecce quam bonum' which had been sung by Savonarola and his followers in the monastery of San Marco in Florence, were sung in Piagnoni communities devoted to keeping his spirit and devotional practices alive, a tendency that was given further emphasis by the tradition of composing polyphonic pieces based on the 'Ecce quam bonum' melody and other texts associated with Savonarola. ${ }^{56}$ Dangerous though it might have been, the singing of Savonarolan laude, with their Republican overtones, was heard in Florentine homes.

In addition to its retrospective and nostalgic character, Razzi's Libro primo was also a major influence on the Roman lauda as it emerged at about the same time. Here the major figures were Filippo Neri, and the composer Giovanni Animuccia, both fellow Florentines who revered Savonarola's memory. Under their influence the final creative phase of the lauda took place with the composition, publication and performance of new laudi for Filippo Neri's Congregazione dell'Oratorio. As with Savonarolan Florence, this took place in a clerical environment of religious reform, both at the Oratory itself, and at the Dominican church of Santa Maria sopra Minerva, where Savonarola's devotional practices were kept alive in a way that was not possible in Medicean Florence. ${ }^{57}$ This included the singing of Marian litanies in front of an altar dedicated to the rosary; the words were published, and could be recited or sung at home. ${ }^{58}$ Similarly, a number of composers connected with the Oratory published laudi to be sung not only during the esercizi spirituali which Neri believed to be a revival of ancient Christian practice, but also in the houses of devotees. Beginning with Animuccia's first book of laude, which includes

55 Macey P., "Some New Contrafacta for Canti Carnascialeschi and Laude in Late Quattrocento Florence", in Gargiulo P. (ed.), La musica a Firenze al tempo di Lorenzo il Magnifico (Florence: 1992) 143-166.

56 Macey P., Bonfire Songs: Savonarola's Musical Legacy (Oxford: 1998).

57 Fenlon I., "Music and Reform: The Savonarolan Legacy", in Fenlon I., Music and Culture in Late Renaissance Italy (Oxford: 2002) 44-66.

58 Litanie della gloriosa vergine Maria di Dio. Lequali si cantano dalle novizi della Minerva ogni sabbato sera \& nelle feste della Madonna avanti l'altare della capella nuova del Santo Rosario (Rome, heirs of A. Blado: 1580). 
simple and essentially homophonic pieces for three and four voices 'for the consolation and needs of many spiritual and devout persons, religious and secular alike', a long series of lauda volumes appeared in Rome. ${ }^{59}$ Although some of this repertory was intended for performance by professional singers, other parts if it were aimed at those of modest abilities. In addition to being sung in church and home, the Roman lauda was an essential feature of the oratorio vespertino, a walk to the Janiculum (a hill in western Rome) organized by the Oratorians. Punctuated with sermons, this took place after vespers on selected feast days and Sundays, and was similar in character to the pilgrimage to the seven principal churches of Rome which Neri had instituted earlier. ${ }^{60}$ Such rituals connected the singing of simpler types of music to both the private and public spheres: the church, the home and the streets of the city.

Savonarola's aim of constructing a civic identity in which the devotional practices of a reformed Church touched the lives of all its citizens was most thoroughly realised neither in Rome, nor in Florence, but in Milan. There the incorporation of music into everyday routine was promoted by the Schools of Christian Doctrine. Initially a specifically Milanese phenomenon, they were well integrated into the fabric of urban life long before their appropriation as an instrument of church and civic reform by Carlo Borromeo following his appointment as Archbishop of Milan in 1565. Staffed by lay confraternities, the Schools aimed to provide children from poor families with religious knowledge, the fundamentals of an elementary education, and basic social and moral values. ${ }^{61}$ With the advent of Borromeo they were brought under ecclesiastical supervision and placed under the control of the parish clergy, in line with the Tridentine decrees. There was now a steep increase in the total number of Schools in the diocese, from just 33 in 1563 , to more than 100 by 1578 , and some 740, almost one for each parish, three years later, when some 40,000 children were being taught by 3,000 confraternity members. ${ }^{62}$ As with so many aspects of Borromeo's project, the spectacular growth of the Schools, and the intensification of their sense of purpose, was characteristic of his conception

59 Giovanni Animuccia, Il primo libro delle laudi [...] (Rome, V. Dorico: 1563).

6o Fenlon, "Music and Reform" 56-57.

61 For the general phenomenon see: Tamborini A., La compagnia e le scuole della dottrina cristiana (Milan: 1939); Grendler P.F., "The Schools of Christian Doctrine in SixteenthCentury Italy", Church History 53 (1984) 319-331; id., Schooling in Renaissance Italy: Literacy and Learning, $1300-1600$ (Baltimore and London: 1989) 333-362.

62 Details from Grendler P.F., "Borromeo and the Schools of Christian Doctrine", in Headley J.M. - Tomaro J.B. (eds.), San Carlo Borromeo: Catholic Reform and Ecclesiastical Politics in the Second Half of the Sixteenth Century (Washington, DC, London and Toronto: 1988) $163-165$. 
that the primary mission of the Church was the salvation of souls through an all-embracing programme of reform designed to penetrate all aspects of personal and public life. In this scheme of things, the education of children was an important element, and music an essential tool.

The Schools met at least once a week for about two hours. Children, some as young as five, were taught the rudiments of reading and writing through the study of simple devotional manuals, above all the catechism, the standard technique being that of rote learning. Some of the basic doctrinal concepts of the Church were also reinforced by the teaching of a handful of easily assimilated melodies, a process that can be followed with great clarity in Diego de Ledesma's textbook Modo per insegnar la Dottrina Christiana, cast in the form of a dialogue between teacher and pupil. ${ }^{63}$ Concerned that all song taught in the Schools must be painlessly learnt, Ledesma advocates that children be encouraged to sing as much of the catechism as possible, with the Ave Maria, Pater Noster, Credo, and Salve Regina as a minimum requirement. ${ }^{64}$ At the end of the book two simple four-voice settings, one of the Ave Maria the other of the Savonarolan text 'Giesu, Giesu, Giesu, Ogn'un chiami Giesu', are provided. ${ }^{65}$ Even those unable to read were catered for through the provision of illustrated books that explain the tenets of the faith as simply as possible through visual means. ${ }^{66}$

In the Schools the simple art of singing litanies was also extensively taught, along with the melodies of monophonic laude, the psalms, and the hymns of the Church. According to the Interrogatorio del maestro, a textbook for the education of children, the practice followed a set formula in which two children, having intoned the melody of each phrase, were then answered by the rest of the group who repeated it. ${ }^{67}$ Psalms could be sung in a similar antiphonal style, with alternate verses being assigned to different voices. Teaching antiphonal singing was seen not only as an aid to domestic devotion, but also as a preparation for participation in parish processions. During the second half of the sixteenth century, not only affordable copies of litanies and psalms, which could

63 Filippi D.V., "A Sound Doctrine: Early Modern Jesuits and the Singing of the Catechism", Early Music History 34 (2015) 1-43.

64 Diego de Ledesma, Modo per insegnar la Dottrina Christiana [...] (Rome, Blado: 1573) fols. 7V, 11-12.

65 For a transcription of the 'Ave Maria' see: Getz C.S., Music in the Collective Experience of Sixteenth-Century Milan (Aldershot: 2005) 247.

66 Giovanni Battista Eliano, Dottrina christiana nella quale si contengono i principali misteri della nostra fede rappresentati con figure per istruttine de gl'idioti \& di quelli che non sanno leggere [...] aggiontovi il Rosario (Rome, G. Ruffinelli: 1591).

67 Interrogatorio del maestro al discepolo per istruir li fanciulli (Milan, Vincenzo Girardoni ad instanza del M. Matteo de Besozzo: 1568). 
be sung to basic recitation tones, but also uncomplicated polyphonic settings of these texts, were produced in increasing numbers. ${ }^{68}$ Most of these editions, probably designed for church choirs of modest abilities, could also have been used at home by musically literate families.

Some form of musical literacy, and with it the ability to sing simple polyphony, was also taught in the Schools of Christian Doctrine. Through such publications as the anonymous Lodi e canzoni spirituali, specifically intended for the Schools, a repertory of simple devotional polyphony was introduced to a wide audience of largely urban schoolchildren. ${ }^{69}$ Similar in style, function, and purpose to the less complicated types of polyphonic lauda, these were designed to be sung communally (that is not by dedicated singers), in oratories, monasteries, and parish churches. And as with the lauda, they could also be sung in a domestic setting, thus connecting the experiences of the local congregation, the centre of collective identity, with those of the home. When the heirs of the Milanese Tini publishing firm produced their broadside catalogue in 1596, one of the earliest from any Italian music printer or publisher to have survived, its contents were dominated, as might be expected given the religious atmosphere of late sixteenth-century Milan, by sacred music that was technically suitable for domestic use: madrigalispirituali, laudi, and falsobordoni. ${ }^{70}$ Indeed, in this period the publication of falsobordoni settings became something of a Milanese speciality, a reflection perhaps of their suitability for Carlo Borromeo's vision of a reformed city. ${ }^{71}$

Yet not just in the towns and cities of Borromeo's sprawling diocese, but throughout Italy, lay religious devotion as practiced in the confraternity meeting house, the parish church, and the family home, was served by a range of music stretching from the monophonic lauda to the more complicated kinds of spiritual madrigal. In between lay a hinterland which spanned the distance between oral traditions, which would have included the chants and hymns of the church and the simplest forms of improvised polyphony, to the least complicated kinds of composed music. To an extent that is now difficult to recover, the most common forms of devotional musical experience were not

68 Rostirolla G., "Laudi e canti spirituali nelle edizioni della prima 'controriforma' milanese", Buzzi C. - Zardin D. (eds.), Carlo Borromeo e l'opera della grande riforma (Milan: 1997) 563-594.

69 Giacomo Ledesma, Lodi e canzoni spirituali per cantar insieme con la Dottrina Christiana (Milan, Pacifico Pontio: 1576).

70 Published with commentary in Fenlon I., "Il foglio volante dei Tini circa il 1596", Rivista italiana di musicologia 12 (1977) 231-251; see also Mischiati O., Indici, cataloghi e avvisi degli editori e librai musicali italiani dal 1591 al 1798 (Florence: 1984) 106-110.

Macchiarelli I., Il falsobordone fra tradizione orale e tradizione scritta (Lucca: 1995) 197. 
the published repertories, but rather improvised devotional music transmitted orally and committed to memory.

Nonetheless, while much was memorized, printed books also played an important role. The propagandistic use of the press was a central feature of Borromeo's campaign, and a number of Milanese presses provided a wide spectrum of material ranging from rulebooks to catechisms, sermons, manuals of Christian behaviour, and collections of prayers and other simple devotions which involved singing. ${ }^{72}$ One such text, the Officium Beatae Mariae Virginis, a miscellany of prayers, canticles, litanies, and psalms, was standardised during the pontificate of Pius v. ${ }^{73}$ The increase in the publication of Catholic spiritual literature, particularly in Italian, during this period, was not so much a revolutionary change as a continuation of existing tendencies. By the end of the century the priority among many printers was to provide functional texts that would guide behaviour in everyday life rather than elaborations of dogma or moral theology. ${ }^{74}$ Catechisms, devotional anthologies, manuals, collections of psalms and other standard prayers (though not the bible which was suppressed in the vernacular) were now available on an unprecedented scale. ${ }^{75}$ By the 1570s Gabriele Giolito, one of the most prolific printers in Venice, was devoting more than two thirds of his catalogue to new and re-issued religious works largely aimed at the professional classes. ${ }^{76}$ There can be little doubt that the Church fostered the spread of private devotion among the members of these social groups through its encouragement and use of the press; even Borromeo was not averse to private prayer, uncontrolled though it might be. This strategy also involved the dissemination of simple music for devotional use, either implicitly by calling on oral traditions, or more explicitly by printing both texts and music together. The content of publications such as the Lodi e canzoni spirituali could be both read and sung in the home using melodies, including secular tunes, taken from the common stock. Another kind of book

72 See Turrini M., "Riformare il mondo a vera vita christiana: le scuole di catechismo nell'Italia del Cinquecento", Annali dell'Istituto storico italo-germanico in Trento 8 (1982) 407-489.

73 Officium beatae Mariae Virginis. Nuper reformatum \& Pii V pont. max. iussu editum (Rome, in aedibus populi Romanum: 1571). See Grendler, Schooling in Renaissance Italy 353-354.

74 Barbieri E., "Tradition and Change in the Spiritual Literature of the Cinquecento", in Fragnito G. (ed.), Church, Censorship and Culture in Early Modern Italy (Cambridge: 2001) $111-133$.

75 For the bible see Fragnito G., La Bibbia al rogo. La censura ecclesiastica e ivolgarizzamenti della scrittura (1471-1606) (Bologna: 1997).

76 Grendler P.F., The Roman Inquisition and the Venetian Press 1540-1605 (Princeton: 1977) 131-134; Nuovo A. - Coppens C., I Giolito e la stampa nell'Italia del XVI secolo (Geneva: 2005); Barbieri, "Tradition and Change" 119-120. See also Richardson B., Printing, Writers and Readers in Renaissance Italy (Cambridge: 1999) ${ }_{137-138}$ and table 6. 


\section{A 257 T V S T E R T I P A R- tis Sacerdotalis.}

C Eompendium Doufice.

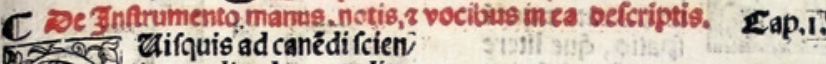
tias erudiendus accedis, i oif́pofitionê, vim, z ozdi


- I nis cantus babet oifcre' tionez) Cozdi memoziter impzimas:vi' delicet,quod ponuntur $a$ funt in ordi' ne manus, feu palme viginti literê: $\tilde{\mathfrak{q}}$ oiuiduntur in fubgrauibus, $z$ graui' bus, acutis $z$ fuperacutis. : At vero infe liere in ozdine manue non funt nifi leptem, voce z forma oifferentes

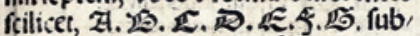
grauis viaeft ountaxat litera greca onnium pzimia in paincipio pollicis manus finiftre a latinis. 1pbilofo, pbis addita:quam quidam eozumvo/ cabulo, Lónima dicunt:ilitos vero la tini vt appellamus, in qua noftre mu' fice omnis fumit ozdo principium: $?$ ipfius LLamma noftra manus oznata initio a ešzectis pfitetur exozdiui fum

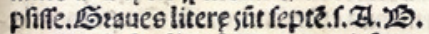



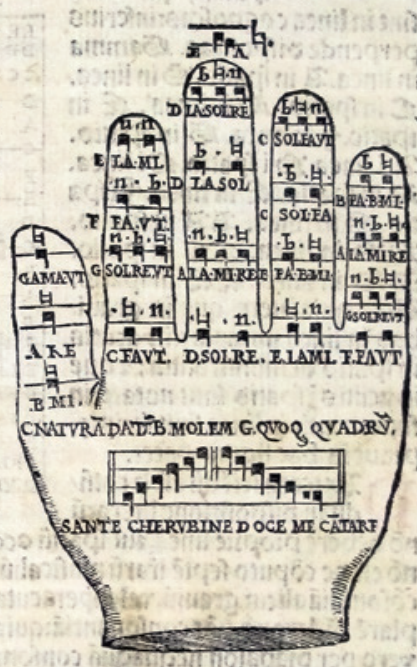
guia in inferiozi loco pzimitus funt

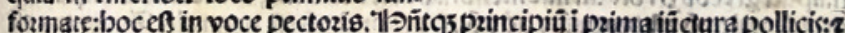



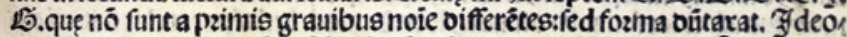


infuperiozi loco.i.in voce gutturie. Ret brit pzincipiâ in tertia iüctura auri cularis:finê vero in frés aiñctura indicis. Souperacute funt quinque, félicet.

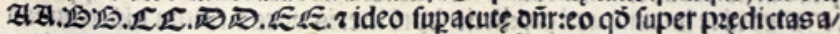
cutas acutiorê reddant fonû. \&Et ratioeft quiaformant in fuperiozi loco.f. in voce capitis, z babent pzincipiấ ill fecáda iuncturamedü, fines vero intertia iunctura eiufdem a tergo, vt omni oepictam banc manum intuenti paset.

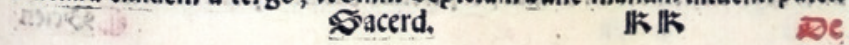

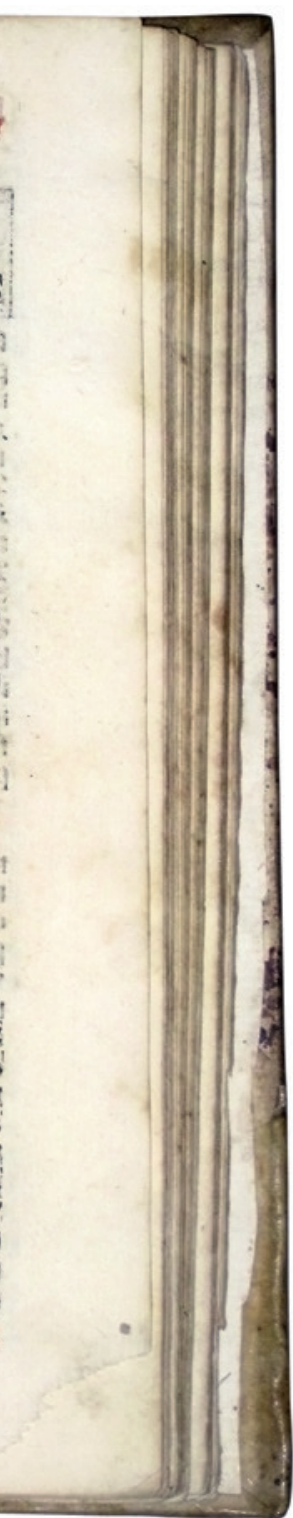

FIGURE 4.5 Compendium musices confectum ad faciliorem instructionem cantum choralem [...] (Venice: Lucantonium de Giunta, 1513). V\&A Libraries, Special Collections, 87.D.28.

(C) VICTORIA AND ALBERT MUSEUM, LONDON 
that takes us in to the more particular private musical world of priests and choirboys is the Compendium musices, an instruction manual for those who were required to sing the liturgy. This opens with a review of the principles of solmisation, illustrated with an image of the Guidonian hand, and then moves on to simple formulas for mutations and the basic chants of the church. ${ }^{77}$ Issued as a separate publication, reprinted many times, and incorporated into editions of the Sacerdotale, the Compendium was aimed at the same audience as the Familiaribus clericorum liber and similar publications. All were essentially do-it-yourself manuals to be studied and followed in private as a guide to singing the liturgy in public. Religious life was not necessarily separate from family life. Although the secular clergy did not marry, they often lived with their mothers or co-habited with their 'housekeepers', effectively forming domestic units. Books such as the Compendium musices were often close at hand [Fig. 4.5].

At the bottom of the hierarchy of book production, both in terms of technical quality and price, chapbooks usually consisted of just two, four, or at most eight pages, poorly produced on cheap paper using worn and antiquated types, sometimes assembled from different fonts. ${ }^{78}$ Often described as 'popular' literature, they were often bought and read by the professional classes as well as those lower down the social scale. In terms of genre, their contents cover a range stretching from extracts from Ariosto's Orlando Furioso, often in dialect, to prognostications, ancient histories, legends from classical antiquity, astrological booklets, and devotional texts; among the latter prayers, laude, and the lives of saints were prominent. ${ }^{79}$ Single-sheet broadsides and prints, the sources of many of the images of Christ and the Virgin that were fixed to the walls and doors of Italian houses, formed part of the same market, and were often produced by the same printers. While the press could bring sacred images into humble homes, broadsides and chapbooks also brought both devotional texts and their music in from the streets and squares of the city. Being cast in ottava rima, many of the poems printed in these cheap formats were intended to be sung to simple melodic formulas drawn from oral tradition, similar to

77 Compendium musices confectum ad faciore instructione cantum chorale discentium (Venice, Giunta: 1513). See Crawford D., "A Chant Manual in Sixteenth-Century Italy", Musica disciplina 36 (1982) 175-190, and for an edition, id., Anonymous compendium musices venetiis, 1499-1597 (n.p.: American Institute of Musicology, 1985).

78 Grendler P.F., "Form and Function in Italian Renaissance Popular Books", Renaissance Quarterly 46 (1993) 451-485.

79 Niccoli O., Prophecy and the People in Renaissance Italy (Princeton: 1990); Javitch D., Proclaiming a Classic: The Canonization of Orlando Furioso (Princeton: 1991); Salzberg R., Ephemeral City: Cheap Prints and Urban Culture in Renaissance Venice (Manchester: 2014). 
those known to have been used to declaim episodes from Ariosto's Orlando furioso. The strambotto, which though apparently similar in structure (it too consists of eight eleven-syllable lines as do many verses in ottava rima) developed independently, could also be sung to a melody that could be indefinitely repeated. ${ }^{80}$ Devotional verses, including versions of the Rosary, were sung in this way. ${ }^{81}$ Performed by cantastorie and cantimpanchi standing on benches and improvised staging to entertain crowds gathered outdoors, these texts could be bought either from pedlars who circulated among the throng or from bookshops. In a domestic setting, these inexpensive print pieces were used for recitation among friends or family, and could be sung to the same tunes.

It is in this hinterland between oral tradition and written forms, rather than in the practices of social elites, that the most common forms of Italian domestic devotional music are to be found. Only one member of the family, standing in the campo as a procession passed or in the piazza when the cantastorie sang, needed to be present in order for texts to travel. That they did so was not only due to their availability in print, but also to the importance of memory and the place of song in everyday life.

\section{Bibliography}

\section{Archival Sources}

Animuccia G., Il primo libro delle laudi [...] (Rome, V. Dorico: 1563).

Castello da A., Liber sacerdotalis (Venice, Sessa and de Ravanis: 1523).

Castello da A., Rosario della Gloriosa Vergine Maria (Venice, Sessa and de Ravanis:1522).

8 o Haar J., "Arie per cantar stanze ariostesche", in Balsamo M.A. (ed.), L'Ariosto e la musica, i musicisti: quattro studi e sette madrigali ariosteschi (Florence: 1981) 31-46; id., "Improvvisatori and their Relationship to Sixteenth-Century Music" in Haar J. (ed.), Essays on Italian Poetry and Music in the Renaissance, 1350-160o (Berkeley, Los Angeles and London: 1986); id., "From 'Cantimbanco' to Court: The Musical Fortunes of Ariosto in Florentine Society", in Rossi M. - Gioffredi Superbi F. (eds.), L'arme e gli amori: Ariosto, Tasso and Guarini in Late Renaissance Florence (Florence: 2004) 179-197; Cavicchi C., "Musici, cantori e 'cantimbanchi' a corte al tempo dell'Orlando Furioso", in Venturi G. (ed.), L'uno e l'altro Ariosto in corte e nelle delizie (Florence: 2011) 263-289; Fenlon I., "Orality and Print: Singing in the Street in Early Modern Venice", in Degl'Innocenti L. - Richardson B. Sbordoni C. (eds.), Interactions between Orality and Writing in Early Modern Culture (Abingdon: 2016) 81-98.

81 Giulio Cesare Grillo, Misteri del santissimo rosario in ottava rima con alcuni sonetti e capitoli spirituali (Rome, T. and P. Diani: 1588); Serafino Razzi, Rosario della gloriosissima Vergine madre di Dio [...] composto nuovamente in ottava rima con alcune annotazione in prosa (Florence, Stamperia del Sermartelli: 1583). 
Compendium musices confectum ad faciore instructione cantum chorale discentium (Venice, Giunta: 1513).

Cooper D., "Devotion", in Ajmar-Wollheim M. - Dennis F. (eds.), At Home in Renaissance Italy (London: 2006) 190-203.

Crawford D., "A Chant Manual in Sixteenth-Century Italy", Musica disciplina 36 (1982) 175-190

Dennis F., "Sound and Domestic Space on Fifteenth - and Sixteenth-Century Italy", Studies in the Domestic Arts 16 (2008-9) 7-19.

Fenlon I., "Music and Reform: The Savonarolan Legacy", in Fenlon I., Music and Culture in Late Renaissance Italy (Oxford: 2002) 44-66.

Fenlon I., "Orality and Print: Singing in the Street in Early Modern Venice", in Degl'Innocenti L. - Richardson B. - Sbordoni C. (eds.), Interactions between Orality and Writing in Early Modern Culture (Abingdon: 2016) 81-98.

Filippi D.V., "A Sound Doctrine: Early Modern Jesuits and the Singing of the Catechism", Early Music History 34 (2015) 1-43.

Fortini Brown P., "Behind the Walls: The Material Culture of Venetian Elites", in Martin J. - Romano D. (eds.), Venice Reconsidered: The History and Civilization of an Italian City-State, 1297-1797 (Baltimore: 2000) 295-338.

Fortini Brown P., Private Lives in Renaissance Venice: Art, Architecture and the Family (New Haven and London: 2004).

Granada de L., Rosario della sacratissima vergine (Venice, Valvassori: 1574).

Grendler P.F., Schooling in Renaissance Italy:Literacy and Learning, 1300-160o (Baltimore and London: 1989).

Grendler P.F., "The Schools of Christian Doctrine in Sixteenth-Century Italy", Church History 53 (1984) 319-331.

Interrogatorio del maestro al discepolo per istruir li fanciulli (Milan, Vincenzo Girardoni ad instanza del M. Matteo de Besozzo: 1568).

Kasl R., "Holy Households: Art and Devotion in Renaissance Venice", in Karl R. Christiansen K. (eds.), Giovanni Bellini and the Art of Devotion (Indianapolis: 2004) 59-89.

Ledesma de D., Modo per insegnar la Dottrina Christiana [...] (Rome, Blado: 1573).

Ledesma G., Lodi e canzoni spirituali per cantar insieme con la Dottrina Christiana (Milan, Pacifico Pontio: 1576).

Macchiarelli I., Il falsobordone fra tradizione orale e tradizione scritta (Lucca: 1995).

Macey P., "The Lauda and the Cult of Savonarola", Renaissance Quarterly 45 (1992) 439-483.

Morse M.A., "Creating Sacred Space: The Religious Visual Culture of the Renaissance Venetian casa", Renaissance Studies 21 (2007) 151-184.

Muir E., "The Virgin on the Street Corner: The Place of the Sacred in Italian Cities", in Ozment S. (ed.), Religion and Culture in the Renaissance and Reformation (Kirksville, MO.: 1989) 7-41. 
Palermo, Biblioteca Nazionale, Rari 1.a.29.32.

Palumbo Fossati I., Dentro le case. Abitare a Venezia nel Cinquecento (Venice: 2013).

Razzi S., Libro primo delle laudi spirituali da diversi eccell. e divoti autori (Venice, ad instantia de' Giunti di Firenze: 1563).

Salzberg R., Ephemeral City: Cheap Prints and Urban Culture in Renaissance Venice (Manchester: 2014).

Venice, Archivio di Stato, Cancelleria inferiore, Miscellanea bb. 34-45.

Venice, Archivio di Stato, Sant'Uffizio b. 15. 